\title{
Evaluation of Serum Prolactin Levels in Hypothyroid Cases of Infertility in Females
}

\author{
Authors \\ M. Indira ${ }^{1}$, Ch. Sudhakarbabu ${ }^{2}$ \\ ${ }^{1}$ MD Asst Professor Dept of Biochemistry, Guntur Medical College, Guntur, Andhra Pradesh \\ ${ }^{2}$ MD Asst Pro of Anatomy, GMC Guntur
}

\begin{abstract}
The present study was undertaken to evaluate the serum prolactin levels in hypothyroid cases of female secondary fertility. Infertility affects 10-15\% of couples of reproductive age groups and female factor is responsible for 40-50\% of cases and one of the important hormone that is serum prolactin also included to evaluate the infertility cases of women in hypothyroidism. Because in thyroid hormone deficient cases also produces infertility in women.

Keywords: serum prolactin hormone, thyroid hormones, infertility.
\end{abstract}

\section{Introduction}

Prolactin may cause infertility in several different ways. first prolactin may stop a women from ovulation . if this occurs a women menstruation will stop. in less severe cases high prolactin levels may only disrupt ovulation once in a while. this would results in intermittent ovulation or ovulation takes a long time to occur. In this category may experience in frequent or irregular periods. Women with mildest cases involving high prolactin levels may ovulate regularly but not produce enough of the hormone progesterone after ovulation. high prolactin levels may cause infertility and also seen in some cases of hyper prolactinemia. Women who are not pregnant and are not breast feeding should have low levels of prolactin. Because of high prolactin levels it is difficulty in becoming pregnant. symptoms of high prolactin levels in women may have no periods or have irregular periods. High serum prolactin levels are seen in hypothyroidism and pituitary adenomas, PCOD and some medications, Eg; the usage of anti depressants, some sedatives, oral contraceptives, verapamil, cimetidien, and stress is also one of the factor to produce high prolactin levels.

\section{Materials and Methods}

To measure prolactin levels, blood drawn in the morning, The women should have had nothing to eat from the night before and should avoid any stimulation of the breast or nipples from the day before and prolactin should also be drawn early in the menstrual cycle before ovulation. this is because prolactin levels are naturally higher after ovulation .there are different forms of prolantin known as isoforms .Not all of the forms cause reproductive problems though all are measure together on a typical prolantin blood test. for this reasons if a prolactin level comes back elevated it should be repeated more detailed test that looks at the different forms individually.

The study included a total of 40 cases of infertility 
cases of women and present study was carried out in the department of OB GYNAEC. The couples with infertility were selected successively and evaluated male factor. A total of 80 women were studied of which 40 were cases and 40 as controls were selected on the bases of normal menstrual history, no systemic illness, no contraceptive history and are fertile, and in good health

\section{Estimation}

Estimation of serum prolactin and thyroid hormones by FIA (Fluoro-immuno assay) method. this method is most sensitive than RIA and ELISA methods .we can detect even $<1 \mathrm{ng} / \mathrm{ml}$ of analyte. And also avoid risk of radiation.

\section{Principle}

Enzyme linked fluorescent Assay are identical to other EIAS except that they use fluorescent Substrates. In the ElFA a florophore is generated by an enzyme reaction.

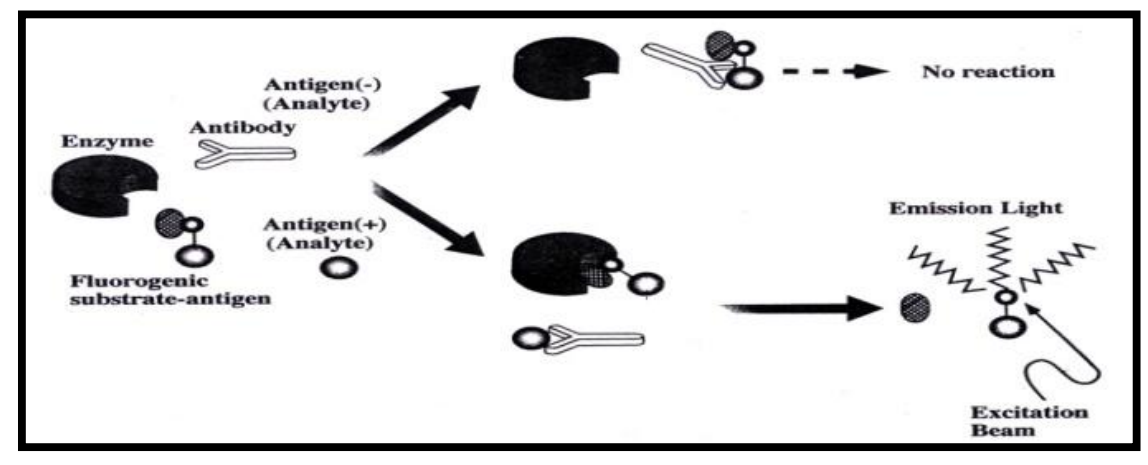

This method is useful for quantitative and some semi-qualitative assays.

\section{If the test value is}

$>$ or =high threshold

$<$ high threshold

$<$ low threshold

\section{the result is}

positive

equivocal

negative

Expected values in this FIA Method

$\mathrm{T} 3=0.92-2.32 \mathrm{mIU} / \mathrm{ml}$

$\mathrm{T} 4=6.0-12 \mathrm{mIU} / \mathrm{ml}$

$\mathrm{TSH}=$ Euthyroid $0.25-5 \mathrm{mIU} / \mathrm{ml}$

Hypothyrod $>7 \mathrm{mIU} / \mathrm{ml}$

Serum prolactin $=$ normal menstruating $5-25 \mathrm{ng} / \mathrm{ml}$

\section{Results}

The disfunctioning of thyroid hormone intern leads to increased of serum prolactin levels which interferes the functions of normal female fertility .The inspiration for this study to know the present

infertility cases of women by analyzing the following biochemical parameters were done 1.T3, T4, TSH, Serum prolactin,

In our present study cases categorized under Normogonadotrophic anovulation have significant low levels of these hormones compared to controls in our present study hypo gonadotrophic anovulation was observed in 40cases with $\mathrm{T} 3$ levels in the range $0.2-0.9 \mathrm{mIU} / \mathrm{ml}$ with mean value of $0.53 \&$ with SD value of + or -0.23 and T4 level in the range of $2.6-5.4 \mathrm{mIU} / \mathrm{ml}$ with mean value of 4.03 and with SD value of +or - 0.81 and TSH level in the range of $6.8-11.8 \mathrm{mIU} / \mathrm{ml}$ with mean value of 9.03 and with SD OF +or -1.76 serum prolactin level with mean value 25.36and SD value of 1.65.result were statistically evaluated using student ' $t$ ' test

$\mathrm{P}$ Value $<0.001$ which is shown to be significant.

Mean and SD VALUES of various biochemical parameters in controles and total cases

\begin{tabular}{|l|c|c|c|c|c|}
\hline \multirow{2}{*}{ S.No. } & \multirow{2}{*}{ Parameter } & \multicolumn{2}{|c|}{ Mean \& SD } & \multirow{2}{*}{ P value } & \multirow{2}{*}{ Remarks } \\
\cline { 3 - 4 } & & Control (40) & Cases (40) & & \\
\hline 1 & T3 & $1.40 \pm 0.71$ & $0.56 \pm 0.23$ & $<0.001$ & Significant \\
\hline 2 & T4 & $8.73 \pm 1.98$ & $4.03 \pm 0.81$ & $<0.001$ & Significant \\
\hline 3 & Prolactin & $15.69 \pm 5.69$ & $25.36 \pm 1.65$ & $<0.001$ & Significant \\
4 & TSH & $2.99 \pm 1.22$ & $9.04 \pm 1.76$ & $<0.001$ & Significant \\
\hline
\end{tabular}




\section{Summary and Conclusions}

Evaluation of serum prolactin levels in hypothyroid cases of female infertility due to ovulatory dysfunction is extremely useful in determination of the diagnosis and also useful in selection of treatment plane and also asses the outcome of the treatment .In our present study variations of serum prolactin levels in patients suffering from ovulatory dysfuction which is seen in hypothyroid cases were significant

\section{References}

1. Bruce R .Carr Disorders of ovaries and Female Reproductive Tract, William text book of Endocrinology $9^{\text {th }}$ edition, 751-817

2. $\mathrm{P}$ reed Larsen et all Thyroid gland, Williams p no418

3. WHO; WHO scientific group on Classification of anovulation

4. Allan G.Gornal, Allan W luxton, Bhagu R Bhavani Endocrine disorders Apllied Biochemistry of clinical disorders $2^{\text {nd }}$ Edition, 285-296

5. Ann M Gronowski Mary Landu-Levine Reproductive Endocrine function Tietz text book of clinical chemistry $3^{\text {rd }}$ Edition 1606-1626

6. Davajan V K Letzky O A Amenorrhea Infertility Contraception and Vol Reproductive Endocrinology $3^{\text {rd }}$ Edition $\mathrm{p}$ 373

7. Rajan $\mathrm{R}$ Reproductive hormones postgraduate Reproductive Endocrinology, $3^{\text {rd }}$ Edition 11-33

8. Babck Imani et al ; ovulation induction in normogonadotophic infertility journal of clinical Endocrinology and metabolism vol 8.3

9. J D Nath et al serum T4 T3 Levels in infertile women Ind Joul valume-40;407-9,

10. Ervin E, Jones ovulatory function evaluation -Amenorrhea decision making infertility, $1^{\text {st }}$ Edition12-21. 